\title{
School Innovativeness as Predictors of School Performance in Malaysian Primary Schools
}

\author{
Kavitha Selvaraja*, Ramli Basri, Abdullah Mat Rashid, Arnida \\ Abdullah
}

Faculty of Educational Studies, Universiti Putra Malaysia; nila_6022@yahoo.com Faculty of Educational Studies, Universiti Putra Malaysia; ramlibasri@upm.edu.my Faculty of Educational Studies, Universiti Putra Malaysia; abmr@upm.edu.my Faculty of Educational Studies, Universiti Putra Malaysia; arnidaa@upm.edu.my

* Corresponding author

To cite this article (APA): Selvaraja, K., Basri, R., Rashid, A.M., \& Abdullah, A. (2021). School innovativeness as predictors of school performance in Malaysia primary school. Journal of ICT in Education, 8(2), 93-109. https://doi.org/10.37134/jictie.vol8.2.9.2021

To link to this article: https://doi.org/10.37134/jictie.vol8.2.9.2021

\begin{abstract}
This study is an attempt to explore the level of school innovativeness and its prediction towards school performance as perceived by teachers. The data was collected using survey questionnaire from the sample of 324 teachers from primary schools in Johor, Perak, Pahang and Selangor. Subsequently, the collected data was analysed using descriptive analysis, One-way ANOVA and multiple regressions. The result showed that Malaysian schools practiced moderate level of innovativeness as overall. However, National Type Tamil schools practiced higher level of innovativeness in comparison with National schools and National Type Chinese schools based on teacher's perception. Apart from that, the result also showed that teachers perceived school innovativeness significantly predict the school performance. With the result obtained, this study proposed some recommendations to the ministry, policy makers as well as researchers to improve school performance in Malaysian primary schools.
\end{abstract}

Keywords: school innovativeness, school performance, Malaysian primary schools, teacher's perception 


\section{INTRODUCTION}

Gauging school performance is crucial in order to warrant quality education. Yet, improving school performance becomes a never-ending challenge for Malaysian schools. Although the Malaysian education system transforms gradually to a more promising system lately, but it is still not meeting the international standard (Malaysian Education Blueprint, 2013-2025, Preschool to Post-Secondary Education). This can be evidenced via international assessments such as Trends in International Mathematics and Science Study 2015 (TIMSS 2015) as well as Programme for International Student Assessment 2009 and 2015 (PISA 2009 \& 2015).

In order to participate and perform well in these international assessments, Malaysia needs a transformation of its entire education system (Malaysian Education Blueprint, 2013-2025, Pre-school to Post-Secondary Education). We need to improve the performance internally before focussing on improvement in international level. Hence, the elements that influence the performance of each school should be identified.

With regards to that, few studies have proved that innovativeness influences organisational performance (Montes et al., 2004; Slater et.al, 2011; Uzkurt, C et. al, 2013; Demirci, 2013). For instance, Montes et al., (2004) stated that organizations with greater innovativeness will become more successful in changing environment and developing new capacities to achieve better performance. In addition, a study in banking industry by Uzkurt, C et al. (2013) also revealed that a superior firm performance can be achieved if the organization adopt and diffuse the innovation. The outcome of these studies is not exceptional to the schools. This is because Haelermans (2011) proposed that effort to implement innovativeness in school is not a waste as it positively affects the school performance. Following this Naz and Murad (2017) highlighted that the use of innovative teaching method enhances the student performance regardless of student diversity. Generally, these findings claimed that innovativeness applied in a school enhances its performance.

As innovativeness produce better performance, Ministry of Education (MOE) encourages Information and Communication Technology in Teaching and Learning as well as in educational management (National Education Policy, MOE). The schools are encouraged to apply new method in teaching and learning by using new digital tool or material which replace the conventional method of teaching and learning. Based on UNESCO (2011-2012) review, Malaysia is the one of the first few countries in the world which has the strategic ICT plan for its education system (Malaysian Education Blueprint, 2013-2025).

However, according to a research carried out by Ministry of Education in 2010, the ICT usage is still limited in schools where it is not beyond the use of power point as a teaching and learning tool. Therefore, Ministry of Education initiated 1BestariNet project in 2011. 
1BestariNet is a system which connects around 10,000 schools nationwide through YES 4G internet in a single platform. This system provides an online learning platform so-called virtual learning environment (VLE) where it allows teachers, parents and students to communicate each other and share the learning resources. Though, the usage of VLE is reported between $0.01 \%$ and $4.69 \%$ only (Official Portal Malaysian Wireless, 2014).

Ministry of Education has taken many initiatives to improve the innovativeness in schools thinking it will improve Malaysian schools' performance. Nevertheless, the level of innovativeness implemented in schools seems not encouraging to support ministry's effort. Therefore, it becomes a need to confirm the level of innovativeness in Malaysian schools and explore if it can predict the school performance. This research can assist to find out what level of innovativeness is sufficient to produce good school's performance. Hence, the aim of this study is as below:

i. To determine the level of school innovativeness in regard to type of primary schools based on teachers' perception.

ii. To determine the difference in the level of school innovativeness in regard to type of primary schools based on teachers' perception.

iii. To determine if school innovativeness predicts school's performance based on teacher's perception.

\section{LITERATURE REVIEW}

A school should not only apply the innovativeness in teaching and learning. The innovativeness should also be applied to school system by introducing more new ideas and activities which not found in other schools. Not only among schools, but a school may also explore new approaches practiced in the other educational institutions (i.e. universities, colleges, vocational education centres and etc) either nationally or internationally and try to adopt it for their school betterment. If the approaches are not suitable, then the school may modify it to suit their school setting, whichever works best.

Wang and Ahmed (2004) claimed that innovativeness of an organization covers five (5) important dimensions as shown in Figure 1: 


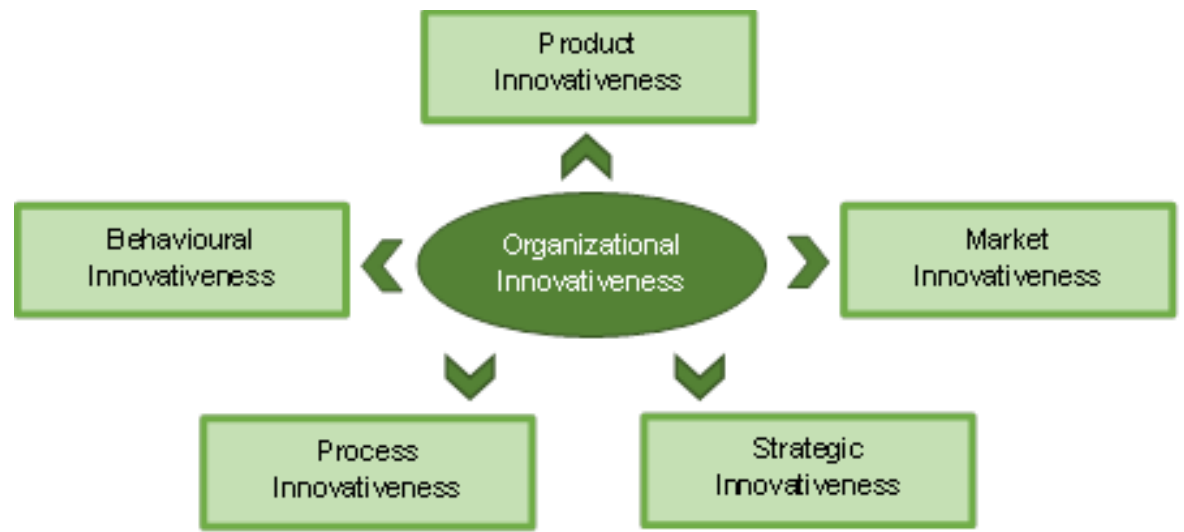

Figure 1: Organizational Innovativeness Construct (Wang \&Ahmed, 2004)

The Organization Innovativeness Construct developed by Wang and Ahmed (2004) provides a clear picture that innovativeness should begin from the behaviour of every individual in the organization and proceeded until it produces a better outcome. Lack of any dimension mentioned in Figure 1 may become a barrier for organizational innovativeness according to Wang and Ahmed (2004).

Behavioural innovativeness is a fundamental and internal based innovativeness dimension that stimulates other dimensions of innovativeness (Mauchet, 2011). According to this model, behavioural innovativeness is measured based on teachers' willingness to take new initiative for school continuous improvement. Wang and Ahmed (2004) highlighted that behavioural innovativeness in an organization cannot be measured by examining any occasional innovation events or innovative characteristics of certain small groups of people in that organization. The organization should reflect some continuous behavioural change toward innovation. That's what truly addressed as behavioural innovativeness.

Behavioural innovativeness is equally critical as other innovativeness because teacher's behaviour towards innovativeness may impact the integration of innovation in school. Therefore, teachers should facilitate the implementation of innovation in their school by incorporating the use of technology and new ideas in their core task. Gosmire and Grady (2007) argued that it is not necessary for school administrators to be experts in the use of technology, but they must have behaviour to accept the technology. The same principle should be applied to teachers also. The teachers should possess acceptance behaviour of innovativeness in order to encourage innovativeness in schools, which is expected to improve the school performance. This has been recommended by Moore (2012) too where the researcher specify the innovativeness through technology implementation. 
As behavioural innovativeness, process innovativeness also an internal based innovativeness (Wang \& Ahmed, 2004). Both dimension of innovativeness are always inter-related. Basically, process innovativeness occurs to improve the internal process in terms of efficiency and effectiveness. Once focus on the behaviour innovativeness, the school should cultivate innovativeness in school processes in order to make changes in the school performance. This can be done by changing the school management style, teaching and learning style and so on as long as it is an internal process.

Besides, strategic innovativeness highlights an organization's ability to recognise external opportunities with internal capabilities. Therefore, it categorised as both internal and external based innovativeness. Basically, strategic innovativeness measured based on how the organization achieved its objectives by creating new strategies with limited resources (Wang \& Ahmed, 2004). As such, the innovativeness element in school strategies is very important so that the school can attained the expected level of school innovativeness to improve its performance.

Unlike behaviour and process innovativeness, market innovativeness considers as externally based innovativeness. According to Wang and Ahmed (2004), market innovativeness achieved through approaches (i.e advertisement and promotion) that used to identify new market opportunities. Innovativeness is not only refers to the introduction of new and unique ideas within the organization. Alternatively, the organization also should explore new ideas from external stakeholders.

Likewise, in order to perform better, the schools are encouraged to look for information on student needs and other school strength and capabilities. The school may explore the new approaches practiced in the other educational institutions nationally or internationally and try to adopt it for school betterment. The school may modify new approaches so that it suits the school setting.

Like market innovativeness, product innovativeness also emphasizes external focus. Even though, the dimension focuses externally, they still require internal support. In school settings, product here refers to any kind of trainings/programmes, system, ideas introduced in school system which will benefit the students, parents and community. Whereas, process refers internal school process which leads to implementation of the product without the presence of students, parents and community.

Product innovativeness include introduction of new system, programmes, technologies and so on. Whereas process innovativeness includes how fast the implementation of new technologies, programmes and system has occurred in the school. Normally, external 
stakeholder interest is in the training and system that has been introduced in the school rather than the internal process on how the training has been introduced.

Ghosh and Srivastava (2018) conducted a study to investigate if Organisational Innovativeness Construct developed by Wang and Ahmed (2004) is robust enough to be remain unchanged across different settings in India. Hence, the study was performed on 481 respondents from various organizations including education settings to determine the construct stability. The result from this study confirmed that Wang and Ahmed (2004) Organisational Innovativeness Construct is indeed a stable construct that maintain its structural consistency in various organizational context including educational context. Hence, this construct has been adopted for the current study to measure school innovativeness.

\section{MATERIALS AND METHODS}

\section{Sampling Procedure}

This study was conducted in Peninsular Malaysia where the schools from east coast, central, northern as well as southern region of Peninsular Malaysia were equally selected. Perak, Selangor, Pahang and Johor were selected to represent each region as these states reported the highest numbers of primary schools.

Cochran's (1977) formula was used to calculate the sample size with $95 \%$ confidence level (t) and 5\% margin error (d). However, the value for estimated proportion of population (p) is not used as .50. This is because the estimated proportion of population was made reference to Malaysia Educational Statistics, 2015 where the proportion of teachers in national schools and non-national schools was reported approximately as 75:25. Hence, the $\mathrm{p}$ and $\mathrm{q}$ value for sample size calculation is estimated as .75 and .25 respectively. The sample size calculated was 288 teachers. However, the sample size was adjusted to accommodate non-response rate by making reference to response rate of pilot study as proposed by Barlett et.al (2001) and Suresh et. al (2012). The final sample size was 324 teachers, after which the sample teachers were further break down into 27 teachers by school type and state using disproportionate stratified random sampling. The samples teachers selected by each school were actually not in the same proportion as they exist in the population. 
School Innovativeness as Predictors of School Performance in Malaysian Primary Schools

Received: 08 June 2021; Accepted: 04 July 2021; Published: 26 August 2021

Table 1: Sample size by state and school type

\begin{tabular}{lcccc}
\hline State & \multicolumn{4}{c}{ Number of Teachers } \\
\cline { 2 - 5 } & SK & SJKC & SJKT & Total \\
\hline Johor & 27 & 27 & 27 & 81 \\
Pahang & 27 & 27 & 27 & 81 \\
Perak & 27 & 27 & 27 & 81 \\
Selangor & 27 & 27 & 27 & 81 \\
\hline Total & 108 & 108 & 108 & 324 \\
\hline
\end{tabular}

According to Fraenkel, Wallen and Hyun's (2012), stratified random sampling is a good sampling as it reduces the chance of selecting a sample which is not a representative of the population. However, stratified random sampling is not appropriate for this study. This is because the sample size for SJKT using stratified random sampling will be very small. Alternatively, the sample size for SK will be very high using the same sampling method. Sample size from either group too small or too large, may not produce a better representative for the study (Sekaran \& Bougie, 2013). In addition, Hair et. al (2010) claimed that smaller samples may results in lower statistical power where it cannot identify significant result and may require additional interpretation or analysis. Hence, for the purpose of this study, disproportionate stratified random sampling was used as it is more appropriate.

\section{Instrument}

To measure school innovativeness, Wang and Ahmed (2004) Organizational Innovativeness Construct (OIC) was used. OIC is as a combination of innovative dimension in terms of product, market, process, behavioural and strategic orientation. The original construct has seven-point Likert scale items. For the purpose of this study, all items were altered into a five-point Likert scale from level 1 (strongly disagree) to level 5 (strongly agree). All the items in this study were modified to suit school settings. Thereafter, the items were translated into Malay and sent to experts in MPWS Rich Publication Sdn. Bhd. in Kajang for its validity verification. In addition, the questionnaire was validated by panel of experts in educational administration in UPM. Besides, a pilot study was conducted to assess the reliability and the questionnaire was reported good internal consistency with Cronbach alpha 97 .

Moreover, even though school performance covers various areas, for the purpose of this study, it is only examines school performance in UPSR examination which assessed using Average School Grade. 


\section{Data Analysis}

First of all, Exploratory Data Analysis (EDA) was carried out to check for errors, missing values and outliers. No errors and missing values were reported. There are only very few outliers with not extreme scores were reported. According to Pallant (2005), detection of outliers in larger samples is common and correction action is not needed.

Thereafter, normality test was carried out. It was reported that the data is distributed approximately normal as the skewness result is between -2 and +2 (Tabachnick \& Fidell, 2007; George and Mallery, 2010) and kurtosis result is between -3 and +3 (Westfall, P.H, 2014). Most of the kurtosis values are only deviates minimally from zero. According to Byrne (2010), standardised kurtosis index has a value of 3, when data are normally distributed. With this, it can be concluded that the data is normally distributed.

The data was proceeded with Kolmogorov-Smirnov test to assess its normality. The test shows significant result (significant value less than .05). This indicates that the data distribution is not normal. According to Pallant (2005), this is quite common for larger samples where the data produces significant result even when the data deviates slightly from normal distribution. Therefore, it is suggested that the assumption of normality should be interpreted together with histograms, Q-Q Plots as well as skewness and kurtosis values.

To further enhance the normality test, the actual shape of data distribution was determined through histogram. The histogram result shows that the data is distributed approximately normal. This is further supported by the normal Q-Q Plot where a reasonable straight line was observed. The homogeneity of variance was also checked for this data.

In this study, the level of school innovativeness was determined based on the mean score obtained from descriptive analysis. The mean score of five-point likert scale was categorised into three level using class interval width formulas as in Table 2. This value is calculated using class interval width formula as below:

$$
\text { Class Interval }=\frac{(\text { Highest Scale Value }- \text { Lowest Scale Value })}{\text { Number of Categories }}
$$

Thus, the class interval value is;

$$
\text { Class Interval }=\frac{(5-1)}{3}=1.33
$$

Thereafter, the calculation of mean score for each level was determined as below.

$1+1.33=2.33$

$2.34+1.33=3.66$

$3.67+1.33=5.00$ 
Table 2: Sample size by state and school type

\begin{tabular}{cc}
\hline Mean Score & Level \\
\hline $1.00-2.33$ & Low \\
$2.34-3.67$ & Moderate \\
$3.68-5.00$ & High \\
\hline
\end{tabular}

Besides, the mean differences comparison among the school type was carried out through One-way ANOVA. A significant $p$ value obtained from this One-way ANOVA analysis indicates that these schools differ significantly in terms school innovativeness.

Besides, the prediction between school innovativeness and school performance was determined using multiple regression analysis. Before analysing using multiple regression, the data were screened for outliers and influential cases using the residual statistics such as cook's distance, leverage and mahalanobis distances. This is because a single outlier or influential case may produce a dramatic effect on the result of the outcome.

\section{RESULT}

The result of this section is organised into two sections. The first section presents the result of school innovativeness level whereas the second section presents result of the prediction between school innovativeness and school performance.

\section{Level of School Innovativeness}

\section{a) School Innovativeness in National Schools}

Table 3 shows the result of school innovativeness for National schools. The school innovativeness is measured by five (5) dimensions. For National schools, two dimensions (2) scores high level and three (3) dimensions scores the moderate level. The dimensions that score high level are Process (Mean=3.93; $\mathrm{SD}=0.59$ ) and Behavioural (Mean=4.04; $\mathrm{SD}=0.57$ ). The dimensions that score moderate level are Product (Mean=3.27; $\mathrm{SD}=0.77$ ), Market (Mean=3.47; $\mathrm{SD}=0.91$ ) and Strategic (Mean=3.58; $\mathrm{SD}=0.74$ ). Among these dimensions, Behavioural recorded the highest mean score, followed by process, strategic, market and product. As a whole, the innovativeness practiced in National schools is at moderate level (Mean=3.66; $\mathrm{SD}=0.72)$.

This result shows that teachers in National schools perceived that their schools practiced moderate level of innovativeness. However, it has to be noted that the behavior innovativeness recorded the highest mean score and product innovativeness recorded the lowest mean score. 
Table 3: Mean and standard deviations for school innovativeness for National schools (Sekolah Kebangsaan, SK)

\begin{tabular}{lccc}
\hline $\begin{array}{l}\text { Innovativeness } \\
\text { Dimension }\end{array}$ & Mean & Standard Deviation & Level \\
\hline Product & 3.27 & 0.77 & Moderate \\
Market & 3.47 & 0.91 & Moderate \\
Strategic & 3.58 & 0.74 & Moderate \\
Process & 3.93 & 0.59 & High \\
Behavioural & 4.04 & 0.57 & High \\
\hline Overall & $\mathbf{3 . 6 6}$ & $\mathbf{0 . 7 2}$ & Moderate \\
\hline
\end{tabular}

Note: $1.00-2.33$ = Low; 2.34-3.67 = Moderate; $3.68-5.00=$ High

\section{b) School Innovativeness in National Type Chinese Schools}

The result of analysis of school innovativeness for National Type Chinese Schools is shown in Table 4. Three (3) dimensions fall under moderate level category and two (2) dimension fall under high level category. Process (Mean=3.69; $\mathrm{SD}=0.65$ ) and behavioural (Mean=3.89; $\mathrm{SD}=0.54$ ) dimensions score high level whereas Product (Mean=3.20; $\mathrm{SD}=0.73$ ), Market (Mean=3.49; $\mathrm{SD}=0.78)$ and $\quad$ Strategic $\quad(M e a n=3.60 ; \quad \mathrm{SD}=0.65)$ dimensions score moderate level. Overall, the result shows that the level of innovativeness in National Type Chinese schools is at moderate level (Mean=3.57; $\mathrm{SD}=0.67)$.

This result shows that teachers in National Type Chinese schools perceived that their schools practiced moderate level of innovativeness. In addition, behavioural innovativeness and product innovativeness recorded the highest and lowest mean score respectively.

Table 4: Mean and standard deviations for school innovativeness for National Type Chinese schools (Sekolah Jenis Kebangsaan Cina, SJKC)

\begin{tabular}{lccc}
\hline $\begin{array}{l}\text { Innovativeness } \\
\text { Dimension }\end{array}$ & Mean & Standard Deviation & Level \\
\hline Product & 3.20 & 0.73 & Moderate \\
Market & 3.49 & 0.78 & Moderate \\
Strategic & 3.60 & 0.65 & Moderate \\
Process & 3.69 & 0.65 & High
\end{tabular}




\begin{tabular}{lccc} 
Behavioural & 3.89 & 0.54 & High \\
\hline Overall & $\mathbf{3 . 5 7}$ & $\mathbf{0 . 6 7}$ & Moderate
\end{tabular}

Note: $1.00-2.33$ = Low; 2.34-3.67 = Moderate; 3.68-5.00 = High

\section{c) School Innovativeness in National Type Tamil Schools}

Table 5 displays the findings of school innovativeness for National Type Tamil schools. All the dimensions, Market (Mean=3.79; $\mathrm{SD}=0.67$ ), Strategic (Mean=3.77; SD=0.73), Process (Mean=3.81; $\mathrm{SD}=0.53$ ) and Behavioural (Mean=3.93; $\mathrm{SD}=0.61)$ score high level except product innovativeness. Product innovativeness (Mean=3.63; $\mathrm{SD}=0.67$ ) scores moderate level. Overall, the result shows that the level of innovativeness in National Type Tamil schools is at high level (Mean=3.79; $\mathrm{SD}=0.64$ ).

This result shows that teachers in National Type Tamil schools perceived that their schools practiced high level of innovativeness. In addition, behavioural innovativeness and product innovativeness recorded the highest and lowest mean score respectively.

Table 5: Mean and standard deviations for school innovativeness for National Type Tamil schools (Sekolah Jenis Kebangsaan Tamil, SJKT)

\begin{tabular}{lccc}
\hline $\begin{array}{l}\text { Innovativeness } \\
\text { Dimension }\end{array}$ & Mean & Standard Deviation & Level \\
\hline Product & 3.63 & 0.67 & Moderate \\
Market & 3.79 & 0.67 & High \\
Strategic & 3.77 & 0.73 & High \\
Process & 3.81 & 0.53 & High \\
Behavioural & 3.93 & 0.61 & High \\
\hline Overall & $\mathbf{3 . 7 9}$ & $\mathbf{0 . 6 4}$ & High \\
\hline
\end{tabular}

Note: $1.00-2.33$ = Low; 2.34-3.67 = Moderate; $3.68-5.00=$ High

\section{d) School Innovativeness by School Type}

Table 6 shows overall score and score by school type for school innovativeness. From this study, it has been noted that overall, the school innovativeness is in moderate level (Mean=3.67; $\mathrm{SD}=0.68$ ) based on teacher's perception. All schools reported behavioural innovativeness as the most practiced innovativeness. However, among the three types of schools, National Type Tamils schools seem good in implementing school innovativeness based on teacher's perception. In addition, the mean score reported statistical significant 
difference at the $\mathrm{p}<.05$ level in school innovativeness for all three type of schools, $\mathrm{F}(2$, 227) $=4.518$.

Table 6: One-way ANOVA Test School Innovativeness by School Type

\begin{tabular}{|c|c|c|c|c|c|}
\hline No. & School Type & Mean & $\begin{array}{l}\text { Standard } \\
\text { Deviation }\end{array}$ & Level & $\begin{array}{c}\text { Innovativeness } \\
\text { that recorded } \\
\text { highest mean } \\
\text { score }\end{array}$ \\
\hline 1 & National Schools & 3.66 & 0.72 & Moderate & Behavioural \\
\hline 2 & $\begin{array}{l}\text { National Type Chinese } \\
\text { Schools }\end{array}$ & 3.57 & 0.67 & Moderate & Behavioural \\
\hline \multirow[t]{2}{*}{3} & $\begin{array}{l}\text { National Type Tamil } \\
\text { Schools }\end{array}$ & 3.79 & 0.64 & High & Behavioural \\
\hline & Overall & 3.67 & 0.68 & Moderate & \\
\hline
\end{tabular}

The Tukey post-hoc test (Table 7) showed that the level of school innovativeness in National Type Tamil schools (mean $=3.79 ; \mathrm{SD}=0.64$ ) is significantly higher than the level of school innovativeness in National Type Chinese schools (mean $=3.57$; $\mathrm{SD}=0.67$ ).

This result means that teachers in National Type Tamil schools perceive that the level of school innovativeness in their schools is significantly higher than National Type Chinese schools.

Table 7: Post Hoc Result for School Innovativeness by School Type

\begin{tabular}{lll}
\hline School Type & Mean Difference & $\boldsymbol{p}$ \\
\hline SK and SJKC & 0.09 & .485 \\
SK and SJKT & 0.13 & .123 \\
SJKC and SJKT & 0.21 & $.011^{*}$ \\
\hline
\end{tabular}

\section{School Innovativeness and School Performance}

Table 8 shows the regression analysis of school performance

Table 8: Result of Regression Analysis

\begin{tabular}{lcccc} 
Variable & b & $\boldsymbol{\beta}$ & $\boldsymbol{t}$ & $\boldsymbol{p}$ \\
\cline { 4 - 5 } & & & & \\
\hline School & .131 & .211 & 2.498 & .013 \\
\hline
\end{tabular}

Note: $\mathrm{R} 2=.042, \mathrm{~F}(3,212)=3.072, \mathrm{p}<.05$ 
A multiple linear regression was calculated to predict school performance based on school innovativeness. A significant regression equation was found $(\mathrm{F}(3,212)=3.072, \mathrm{p}<.013)$, with an R2 of .042. School performance is increased 0.211 units for each unit of school innovativeness. Hence, school innovativeness is a significant predictor of school performance based on teachers' perception. This means that primary schools may improve its performance if they have clear strategic direction and support for innovativeness in order to meet its objectives.

\section{DISCUSSION}

\section{Level of School Innovativeness}

\section{a) School Innovativeness in National Schools}

National schools practiced moderate level of innovativeness based on teachers' perception. Nevertheless, teachers perceived that behavioural innovativeness is the most practiced innovativeness.

This means that the teachers in National schools perceived that their existing school system remains conventional where there is no improvement in the system. Nevertheless, the teachers support their peers if they want to bring any new initiative for school success. They do not discourage the ideas, alternatively they work along with their peers to convert the ideas into school profit. This result may not be comparable with previous studies as there are limited studies on the school innovativeness by Wang and Ahmed (2004) in school context.

Having a higher of level of behavioural innovativeness is considering a good sign of creating an innovative culture. This is because behavioural innovativeness is a fundamental factor in order to produce a higher level of school innovativeness. Teachers should be receptive to the innovativeness in the first place. Then only, the innovativeness concept can be disseminated to the school processes, and ultimately produce an expected product in the school system.

\section{b) School Innovativeness in National Type Chinese Schools}

Teachers in National Type Chinese schools perceived that their schools practiced moderate level of innovativeness. However, it has to be noted that behavioural innovativeness is the most practiced innovativeness based on teacher's perception.

This means that the teachers in National Type Chinese schools have similar perception as teachers in National schools where the teachers feel that their schools do not pay much interest in implementing innovative ideas in schools. However, the teachers are committed 
to welcome more new ideas. Therefore, the behavioural innovativeness recorded the highest mean score.

Financial issue could be one of the possible reason to have moderate level innovativeness in these schools. It is revealed via Ghavifekr et. al (2017) study that National Type Chinese schools facing challenges to upgrade their school facilities such as computer software as the government funding allocation is insufficient for the schools. The teachers in these schools need to organize fund raising campaign in order to collect money from parents that takes up their time and effort. In addition, the same study highlighted that the senior teachers in these schools are not welcoming any change and still using old method of teaching despite repetitive request from headmasters. The findings from Ghavifekr et. al (2017) study confirms level of innovativeness recorded through this study.

c) School Innovativeness in National Type Tamil Schools

Teachers in National Type Tamil schools perceived that their schools practiced high level of innovativeness. Like the other schools, behavioural innovativeness and product innovativeness recorded the most and least practiced innovativeness.

The most practiced behavioural innovativeness indicates that teachers in National Type Tamil schools encourage new ideas in school processes whereby it leads to exploration of new opportunities outside the school compound. The innovativeness starts implemented in teachers behaviour and gradually improved until exploring the market opportunities. Nevertheless, these schools still not reached the stage to introduce new programme or training to other educational institutions. That's why, the product innovativeness reported the lowest mean score.

\section{d) School Innovativeness by School Type}

The result shows that National and National Type Chinese schools practiced moderate level innovativeness based on teachers' perception. Whereas, teachers in National Type Tamil schools perceived that their schools practiced high level of school innovativeness. In all primary schools, behavioural innovativeness recorded the highest mean score and product innovativeness recorded the lowest mean score.

This result implies that National Type Tamil schools seem to have an underlying elements of innovation outcomes starting from its teachers' behavior, school processes as well as its strategic innovative orientation. However, the introduction and usage of new technologies seems lacking at the moment. Therefore, product innovativeness still in moderate level compared to other innovativeness. Though, overall, the innovativeness practiced in National Type Tamil schools is in high level. 
Unlike National Type Tamil schools, teachers in National schools and National Type Chinese schools perceived that their schools' innovativeness is in moderate level. The implementation of innovativeness is only observed in teacher's behavior and school internal processes. These schools still need to improve in terms of its strategic planning, exploring new ideas from external parties as well as leveraging new technologies.

The result of this study reflects the teacher's view on the recent announcement for Google classroom implementation. Many teachers are quite excited that the Google classroom will take effect starting July 2019, replacing the existing Frog VLE. It was noted that the Google classroom has been in place in some schools even though it is not an official platform under Ministry of Education (The Star Online, 2019). This shows that teachers in Malaysian primary schools are keen in innovative teaching and learning.

The practice of innovativeness is also generally in place in primary schools. Nevertheless, the level of implementation varies across primary schools whereby moderate innovativeness reported in National and National type Chinese schools. This is in line with the news released in The Star Online, 2019 where the Google classroom is already in use in some schools even though it is not an official platform under Ministry of Education. This news confirms that the innovativeness is existing in primary schools.

\section{School Innovativeness and School Performance}

This study reveals that school innovativeness significantly predict the school performance. This study is quite comparable with the following study (Rhee, Park, \& Lee, 2010) where the innovativeness significantly impacts the performance of an organisation. The primary schools may improve its performance if they have clear strategic direction and support for innovativeness in order to meet its objectives. Hence, it can be confirmed that the innovativeness in schools may improve the Malaysian schools performance, which subsequently can meet the international standard. It is understood that teachers are keen and supportive to the innovativeness implementation plan. It is just that the usage of new technologies in primary schools is not wide enough. However, these teachers' interest will definitely speed up the implementation of innovativeness in schools that will eventually improve its performance.

\section{CONCLUSION}

This study proves that school innovativeness is the significant predictors of school performance based on teacher's perception. However, the usage of new technologies in schools is not wide enough. Hence, school headmasters, policy makers as well as Ministry of Education need to analyse the innovativeness practiced within each school and do the necessary change for the school betterment. For instance, Ministry of Education may 
allocate more budgets for schools to improve its innovativeness. The ministry should ensure all the schools being upgraded with new technologies to stay competitive with the world education market. Not only ministry, headmasters also may explore the innovation practice from other industries to be considered for implementation in their schools. As improvement of innovativeness requires great effort and longer time, all the relevant parties must work together instead of working individually.

It cannot be denied that this study becomes a basis for future studies to analyse the relationship between school innovativeness and school performance. A similar study can be conducted in secondary schools with different research approaches for better generalization. In between, the current study measures school innovativeness based on teachers perceptions. Hence, there is a need to consider headmaster's view in evaluating school innovativeness towards performance. This is because how the headmaster see the school innovativeness may not be same as how the teachers see the environment. Thus, a future research which considers the headmaster's perception may add more value to this study.

Furthermore, this research is a quantitative survey research. In order to support and strengthen the findings of this study, we need a qualitative research. Therefore, it is recommended to conduct a qualitative research to examine the challenges face by schools to implement innovativeness which improve the school performance. Individual teacher's perception on school environment can be identified through qualitative research.

Besides, the Malaysian Universities may encourage its postgraduate students to do more researches in relation to school innovativeness and school performance. The universities should highlight the importance of improving the school performance for future nations to their students. The ministry also should support universities by allocating more research grant.

\section{REFERENCES}

Cochran, W. G. (2007). Sampling techniques. John Wiley \& Sons.

Demirci, A. E. (2013). Strategic representation of an abstract reality: Spiraling relations between organizational culture and innovativeness. Journal of Management and Strategy, 4(3), 39 https://doi.org/10.5430/jms.v4n3p39

Fraenkel, J. R., Wallen, N. E., \& Hyun, H. H. (2012). How to Design And Evaluate Research in Education. (8th edt.). New York: McGram-Hill Companies.

Ghavifekr, S., Hoon, A. L. S., Ling, H. F., \& Ching, T. M. (2017). Heads of departments as transformational leaders in schools: Issues and challenges. MOJEM: Malaysian Online Journal of Educational Management, 2(3), 119-139.

Ghosh, S., \& Srivastava, B. K. (2018). Rescaling Organizational Innovativeness: The Indian Context. Global Business Review, 19(1), 241-255. https://doi.org/10.1177/0972150917714112 
School Innovativeness as Predictors of School Performance in Malaysian Primary Schools

Received: 08 June 2021; Accepted: 04 July 2021; Published: 26 August 2021

Gosmire, D., \& Grady, M. (2007). A Bumpy Road: Principal As Technology Leader. Faculty Publications in Educational Administration

Mauchet, M. (2011). Managers' perceptions of organizational learning and organizational innovativeness in a global healthcare organization (Doctoral dissertation, The George Washington University).

Montes, F. J. L., Moreno, A. R., \& Fernández, L. M. M. (2004). Assessing the organizational climate and contractual relationship for perceptions of support for innovation. International Journal of Manpower, 25(2), 167-180. https://doi.org/10.1108/01437720410535972

Moore, P.R. Exploring relationships between personal innovativeness and acceptance of technology of school administrators. Ph.D. thesis, The University of West Florida

Naz, F., \& Murad, H. S. (2017). Innovative teaching has a positive impact on the performance of diverse students. SAGE Open, 7(4), 1-8. https://doi.org/10.1177/2158244017734022

Official Portal Ministry of Education Malaysia. (2021). Retrieved from www.moe.gov.my

Official Portal Malaysian Wireless (2021). Retrieved from www.malaysianwireless.com

Rhee, J., Park, T., \& Lee, D. H. (2010). Drivers of innovativeness and performance for innovative SMEs in South Korea: Mediation of learning orientation. Technovation, 30(1), 65-75. https://doi.org/10.1016/j.technovation.2009.04.008

Slater, S. F., Olson, E. M., \& Finnegan, C. (2011). Business strategy, marketing organization culture, and performance. Marketing letters, 22(3), 227-242. https://doi.org/10.1007/s11002-010-9122-1

Suresh, K. P., \& Chandrashekara, S. (2012). Sample size estimation and power analysis for clinical research studies. Journal of human reproductive sciences, 5(1), 7-13. https://doi.org/10.4103/0974-1208.97779.

Uzkurt, C., Kumar, R., Semih Kimzan, H. and Eminoğlu, G. (2013), Role of innovation in the relationship between organizational culture and firm performance: A study of the banking sector in Turkey, European Journal of Innovation Management, 16 (1), 92-117. https://doi.org/10.1108/14601061311292878

Wang, C. L., \& Ahmed, P. K. (2004). The development and validation of the organisational innovativeness construct using confirmatory factor analysis. European Journal of Innovation Management, 7(4), $303-$ 313. https://doi.org/10.1108/14601060410565056 